\title{
Kinder, gentler, more useful mathematics
}

\section{Washington}

THE most prestigious graduate mathematics programmes at US universities attract, naturally enough, the brightest undergraduates. But some of the most highly reputed mathematics departments in the country, having taken in the cream of the crop, do little to enrich it. In some cases, a majority of those enrolled never even finish their degrees.

While some defend this failure rate as proof of the intellectual rigor of the subject, a new report from the National Research Council (NRC)* on doctoral education in the mathematical sciences comes to a simpler but heretical conclusion: many traditional doctoral programmes serve their students, and society in general, badly indeed.

The NRC report, issued last week, was based on scrutiny of graduate programmes in mathematical sciences (including statistics and operations research, for example, as well as the traditional areas of pure and applied mathematics) at ten universities. Their names were concealed to encourage candour among faculty members and, especially, students who were interviewed. These programmes were selected for demonstrating unusual success in better completion and placement rates and higher proportions of women and minority students.

The most evident conclusion from this informal survey was the common-sense one: students invariably did better and were happier in programmes where the faculty took pains to encourage and guide them. They stand apart from what Avner
Friedman, from the Institute of Mathematics and its Applications at the University of Minnesota, calls the "traditional European elitist" system, in which graduate students are expected to produce a thesis after several years' effort or else to pass silently from the scene.

In early drafts of the report, recalls Rhonda Hughes of Bryn Mawr College, there were repeated references to such phrases as "nurturing environment" and "positive learning experience". Their appearance was so startling, she says, that most were cut out in the final report to lessen the shock to the mathematical audience. The gratifying aspect of their study, says Hughes, was that the ingredients needed for success are things that do not cost money; unfortunately, she adds, they are also the things that money can't buy.

Perversely, programmes that are successful in the ways measured by the report still may have trouble attracting students. Experience with her own undergraduates at Bryn Mawr has taught Hughes that 'big name' schools hold a strong attraction despite her warnings that the elite universities will not be comfortable with, and may not even offer, the variety of research disciplines that will best suit the individuals' talents and career prospects. Foreign students likewise face pressure to attend the most famous university their parents have heard of.

But there are indications that the new approach also appeals to students. Programmes that have actively sought to distingush themselves from the traditional mathematics departments and which have made efforts to recruit new students find that they can fill as many as 80 per cent of their places with domestic students. That is quite an accomplishment at a time when, overall, more than half of the mathematical sciences doctorates in the United States are awarded to foreign students. Women and minorities comprise as much as 30 per cent of such classes.

Although the aim of the survey was to improve the quality of life for graduate students, socially and perhaps politically useful lessons may come of it. Ronald Douglas of the State University of New York at Stony Brook, and chair of the committee that produced the report, sees the potential for a wholesale change in the way that the mathematical sciences are conducted. Through departments that have made extra-academic contacts, business and industry are waking up to the idea that they need people whose speciality is something called mathematics. Most mathematicians now working for US industry, he says, are disguised as engineers and physicists because mathematics itself sounds too removed from the real world.

The change in strategy extends beyond the newer and less celebrated departments. It is beginning to dawn on faculty at even the most prestigious institutions that a $\mathrm{PhD}$ completion rate of less than half is a symbol not of quality but a sign that the system is not working. David Lindley

* Educating mathematical scientists: doctoral study and the postdoctoral experience in the United States. National Research Council, April 1992.

\section{Maastricht drives R\&D to the market}

\section{London}

IDEAS with clear commercial potential will receive the most attention in the next fiveyear plan to cover research and development (R\&D) by the European Commission (EC). The approach, described last week by Filippo Pandolfi, commissioner for $R \& D$, is a response to negotiations last December at Maastricht, where the EC heads of government pledged to make their countries more competitive in global markets.

Although science per se barely got a look-in at the summit - a move to change the voting system that allocates funds was considered briefly and rejected in the dying minutes of the summit $-R \& D$ is getting a boost, says the Commission, to "reflect the ambitions of the treaty".

Among other things, the Commission is concerned about the proportion of gross domestic product that its 12 members spend on R\&D. Last year that figure was 2.1 per cent, compared to 2.8 per cent by the United States (which includes military spending) and 3.5 per cent by Japan. It is also worried that $R \& D$ linked to industrial activities does not receive enough attention, and it wonders why European companies find it so difficult to convert their $\mathrm{R} \& \mathrm{D}$ activities into inventions and their inventions into profits.

In response, Pandolfi said that the total resources for Community $R \& D$ would be increased from 2,400 million ecu (US\$2,950 million) in 1992 to 4,200 million ecu (US $\$ 5,150$ million) in 1997 . Even so, the rise falls short of the 5,400 million ecu that Pandolfi said he was aiming for in January (see Nature 355, 3; 1992). As well as maintaining existing programmes, this money must also pay for the Commission's intention to become more involved in such 'big science' projects as thermonuclear fusion, global change and the human genome.

While the proposals for these projects will be submitted by individual compa- nies, the idea is that the technologies involved will benefit European industry as a whole. The Commission is especially interested in supporting such areas as micro-electronics and high-performance computing, advanced molecular biology and environment-friendly industrial technologies.

At the same time, the new approach to near-term research sails close to breaking the rules, which say that the Commission can only support research projects that do not distort competition in the market place. The Commission hopes to uphold that rule by building networks into each project to ensure that each company interested in the results has the chance to exploit them.

Although EC research will be increased significantly if these proposals are approved, it remains a very small part of R\&D in Europe. At present it represents less than 4 per cent of the total financial resources allocated to $R \& D$ by the member states of the Community. Ian Mundell 